\title{
Evaluation of the antidiarrheal activity of $80 \%$ methanol extract and solvent fractions of the leaf of Bersama abyssinica fresen (Melianthaceae) in mice
}

\author{
Mihret Ayalew ${ }^{1 *}$, Azmeraw Bekele $^{2}$, Mestayet Geta Mengistie ${ }^{3}$ and Seyfe Asrade Atnafie ${ }^{3}$
}

\begin{abstract}
Introduction: The use of traditional medicinal plants in the management of diarrhea has long been practiced in Ethiopia. B. abyssinica fresen is one of the plants traditionally used to treat diarrhea whereas an in vivo study had not yet been conducted. Thus, this study aimed to evaluate the antidiarrheal activity of crude extract and solvent fractions of the leaf of B. abyssinica in mice.

Methods: Cold maceration within $80 \%$ methanol was used to extract the leaf powder and extract of the leaf was fractionated using n-hexane, chloroform, and distilled water. The in vivo antidiarrheal activity of crude extracts and solvent fractions were tested in experimental models of castor oil-induced diarrhea, enteropooling, and antimotility test. Five groups each with 6 mice were used under the three antidiarrheal models. Positive controls were treated with loperamide $3 \mathrm{mg} / \mathrm{kg}$ and atropine $5 \mathrm{mg} / \mathrm{kg}$ and $2 \%$ tween 80 was used in the treatment of negative controls. The extract and solvent fractions were administered at doses of 100, 200, and $400 \mathrm{mg} / \mathrm{kg}$. Time of onset of diarrhea, number and weight of total and wet feces, the percent reduction in the number of wet feces, weight and volume of intestinal contents, and percent inhibition of intestinal motility were recorded. Data were analyzed using SPSS version 20.

Result: Defecation of castor oil-induced diarrheal or loose stools was inhibited ( $p<0.01$ to $p<0.001)$ at $200 \mathrm{mg} /$ $\mathrm{kg}$ and $400 \mathrm{mg} / \mathrm{kg}$ of crude extract and aqueous fraction. The crude extract and the aqueous fraction at three doses ( $p<0.01$ to $p<0.001$ ), the chloroform fraction at $200 \mathrm{mg} / \mathrm{kg}$ and $400 \mathrm{mg} / \mathrm{kg}(p<0.01$ to $p<0.001)$, and the n-hexane fraction at $400 \mathrm{mg} / \mathrm{kg}(p<0.05)$ reduced intraluminal fluid accumulation compared with the negative control. Castor oil-induced intestinal motility was significantly suppressed with the three-doses of aqueous fraction $(p<0.05$ to $p<0.001), 200 \mathrm{mg} / \mathrm{kg}$ and $400 \mathrm{mg} / \mathrm{kg}$ of crude extract ( $p<0.05$ to $p<0.01), 400 \mathrm{mg} / \mathrm{kg}$ of chloroform and $\mathrm{n}$-hexane $(p<0.01$ to $p<0.001)$ compared with negative control.
\end{abstract}

Conclusion: The crude extract, aqueous, and chloroform fractions of B. abyyssinica leaves have promising anti-diarrheal effects, supporting the plant's traditional use to treat diarrhea.

Keywords: In vivo, Antidiarrheal, Bersama abyssinica, Castor oil, Mice

*Correspondence: kealikyas24@gmail.com

1 Department of Pharmacology, Institute of Health, Jimma University, Jimma, Ethiopia

Full list of author information is available at the end of the article

\section{Introduction}

Diarrhea is defined as three or more bowel movements associated with abnormally loose or liquid stools. The frequency, consistency, and weight of stool are taken 
into account to identify diarrhea [1]. Diarrhea is forced by osmotic and active secretion, with impaired peristalsis and exudation $[2,3]$. There are three diarrheal syndromes; acute diarrhea $(250 \mathrm{ml} / \mathrm{kg} /$ day of water loss in the stool), bloody diarrhea (with visible blood in the stool), and persistent diarrhea (which lasts two weeks or more). Acute watery diarrhea with dehydration is the leading cause of death from diarrhea [4]. Every year, 1.7 billion cases of diarrhea in children and 525,000 deaths in under-age five children are reported. About half of these diarrheal diseases are reported in South Asia and Africa. Children mortality rates from diarrhea are highest in subSaharan Africa [2, 3], while Ethiopia has the fifth-highest diarrhea burden in the world $[2,4]$.

Diarrhea is both preventable and treatable. However, the treatment of diarrhea is limited by unsafe, ineffective, contraindication of antidiarrheal drugs [1], and/ or development of resistance [4,5]. Medicinal plants (MPs) are the most important and sometimes the only source of diarrhea treatment. Because MPs are culturally accepted, accessible, and inexpensive compared to modern medicine, nearly $80 \%$ of the Ethiopian population uses MPs [1].

Bersama abyssinica (B. abyssinica) fresen belongs to the Melianthaceae family and the genus Bersama [1]. It is a small evergreen tree 12 to $25 \mathrm{~m}$ high and its leaves are alternate, impair innately compound and consist of 12 pairs of opposing leaflets with 10-12 pairs of lateral veins. B. abyssinica is distributed from Guinea Bissau through the coastal countries of West Africa except for Benin, to the east in Eritrea and Ethiopia, and the south in Angola, Zambia, Zimbabwe, and Mozambique. In Ethiopia, B. abyssinica is called Azamir (Amharic), and Lolchissa (Oromeffa) [2].

B. abyssinica fresen is rich in various secondary metabolites responsible for the drug's effects in the treatment of various ailments. The stem bark of B. abyssinica is rich in phenols, flavonoids, and saponins [1]. Methanolic fraction of leaf, stem bark, and root bark of B. abyssinica contained flavonoids, terpenes, steroid, carotenoid, unsaturated, and saturated fatty acids [6]. The methanolic and chloroform extracts of the leaves of the plant are rich in alkaloids, glycosides, and flavonoids, while the methanolic extract of the leaves contained; steroids, phenols, tannins, triterpenes, anthraquinones, polysterols, and coumarin (3). The aqueous extract of the leaves contains phenolic compounds such as; flavonoids and tannins [4].

B. abyssinica fresen is traditionally used to treat various ailments. Among various parts of the plant used, the decoction of the leaves is widely used to treat many stomach ailments such as abdominal pain, diarrhea, cholera, intestinal worms, amoebiasis, and dysentery [5]. The stem bark and root bark of B. abyssinica, in Ethiopia, is used to treat dysentery, syphilis, and ascariasis [7]. A leaf decoction is used to treat ringworm [8, 9], stomache [10], and diarrhea [11].

Different traditionally claimed activities of B. abyssinica fresen leaf extracts including antidiabetics, antioxidants [4], antimalarial [12], antibacterial [3, 13], anthelmintic [14], antiviral [15], and antifungal [16] have been demonstrated in vitro and/or in vivo studies. Moreover, the aqueous extract from the leaves of B. abyssinica had spasmolytic activity on isolated guinea-pig ileum [17]. Nevertheless, the in vivo antidiarrheal activity of the plant has not been investigated yet. Hence, this study aimed to evaluate the in vivo antidiarrheal activity of the leaves of B. abyssinica fressen.

\section{Methods \\ Animals}

Swiss albino mice aged between 6 and 8 weeks and weighing between 20 and $35 \mathrm{~g}$ breeding in the animal house of the department of pharmacology, the University of Gondar, was used to test for antidiarrhoeal activity. Animals were kept under standard conditions room with $12 \mathrm{~h}$ of light and dark cycles. Animals were fed a standard pellet diet and water ad libitum. Before the experiment, animals were acclimatized for a week under laboratory conditions. Animals were handled and used per international guidelines for the care and use of laboratory animals [18].

\section{Plant material collection and authentication}

Fresh leaves of $B$. abysinica fresen were collected from Alem Saga, in the South Gondar zone, in the national state of Amhara, and $154 \mathrm{~km}$ from the city of Gondar at $38^{0} 1^{\prime} \mathrm{E}$ of longitude and latitude of $11^{0} 51^{\prime} \mathrm{N}$ with an elevation of $2706 \mathrm{~m}$ on 25 January 2020. It was transported by wrapping it in a plastic bag. The leaves were identified and authenticated by the botanist of the University of Gondar, Mr.Abiyu Eniyew Molla, and registered with voucher No.001MAT/2020 has been deposited in the herbarium of the Department of Biology, University of Gondar, for future reference.

\section{Plant extraction and solvent fractionation}

The collected leaves were washed to remove dust particles and dried under shade at room temperature for a week. The dried leaves were crushed into a coarse powder with a mortar and pestle. The resulting powder was measured on digital balance (EPH 00 Abron Exports) and obtained $1000 \mathrm{~g}$. The $1000 \mathrm{~g}$ of powder was cold macerated using 
three Erlenmeyer conical flasks of equal size, each containing $2 \mathrm{~L}$ of $80 \%$ methanol (Meru Chem Pvt. Ltd). It was allowed to wait 3 days with occasional shaking. On day 4, the macerate was first filtered through gauze, followed by Whatman No.1 filter paper. The residue in each macerating flask was re-macerated twice using the same amount of $80 \%$ methanol used in the first maceration. Meanwhile, the filtrates were combined and concentrated in a rotary evaporator (Yamato Scientific CO. Ltd, Japan) at $40^{\circ} \mathrm{C}$. The filtrate concentrate was frozen in a deep freezer $\left(-20^{\circ}\right.$ C) overnight. Then, the water content of the frozen filtrate was removed by lyophilization within a vacuum freeze dryer (Lab Freeze Instruments Group, Ltd, Germany) at $-50^{\circ} \mathrm{C}$ and under vacuum pressure $(200 \mathrm{mBar})$. Finally, the dried filtrate (crude extract) was well packed and refrigerated at $-4{ }^{\circ} \mathrm{C}$ until use.

From the crude extract, $55 \mathrm{~g}$ was fractionated using n-hexane (Pentoky organy, India LTD), chloroform (Carlo ERBA S.A.S reagent), and distilled water (Ethiopia Pharmaceutical Factory, Ethiopia). The measured amount was first dissolved in a $1000 \mathrm{ml}$ glass beaker with $250 \mathrm{ml}$ of distilled water, followed by an equal volume of $n$-hexane. The bulk solution was suspended in a $500 \mathrm{ml}$ separating funnel and left to stand for a few hours under occasional stirring until a clear layer was formed. After two clear layers formed, the n-hexane content was filtered out. The residue was re-macerated twice with the same volume of n-hexane and in the same way as for the first maceration. Then the filtrate fractions were combined and used as the n-hexane fraction (NHF). The $250 \mathrm{ml}$ of chloroform was added to the residue and repeated in the same manner as n-hexane. The chloroform layer was then separated from the residue and used as the chloroform fraction (CF). The final residue was used as an aqueous fraction (AF). NHF and CF were concentrated on a rotary evaporator and dried in a hot oven (Medit Medizin Technik, Germany) at $40{ }^{\circ} \mathrm{C}$ and the AF was lyophilized. Finally, the fractions were kept in the refrigerator until the time of use. After all, the yield of both the crude extract and the solvent fraction was calculated according to the following formula [19].

$$
\text { \%yield }=\frac{\text { weight of the extract }}{\text { Weight of plant material }} \times 100
$$

The percentage yield of the crude extract was $17.30 \%$, while AF, CF, and NHF were $63.64 \%, 13.09 \%$, and $4.18 \%$, respectively.

\section{Grouping and dosing of the animal}

The mice were randomly grouped into five groups, each containing six mice. These groups were designated as negative controls (group I), positive controls (group II), and the remaining three treatment groups. Negative control mice were treated with $2 \%$ tween $80(10 \mathrm{ml} / \mathrm{kg})$. At the same time, positive controls were treated with loperamide (Brawn Laboratories Ltd, India) (3 $\mathrm{mg} / \mathrm{kg}$ ) for castor oil-induced diarrhea, enterpooling models, and atropine sulfate (Reyoung Pharm) $(5 \mathrm{mg} / \mathrm{kg}$ ) for the antimotility testing model. The three treatment groups were treated with doses of $100 \mathrm{mg} / \mathrm{kg}$ (group III), $200 \mathrm{mg} / \mathrm{kg}$ (group IV), and $400 \mathrm{mg} / \mathrm{kg}$ (group V) of crude extracts or solvent fractions. These doses were determined based on previous acute toxicity studies results that showed $\mathrm{LD}_{50}$ of the leaf extract was greater than $2000 \mathrm{mg} / \mathrm{kg}[11,20]$. The doses of crude extracts and solvent fractions were determined from $2000 \mathrm{mg} / \mathrm{kg}$ in that one-tenth used as the middle dose. One-half and double of the middle dose are used as the low and high dose, respectively [21].

\section{Antidiarrheal activity testing Castor oil-induced diarrhea}

The antidiarrheal activity of the crude extracts and the solvent fractions was tested according to the method used by Awouters et al. [22]. The mice were fasted for $18 \mathrm{~h}$ for food but had free access to water. The fasted mice were randomly grouped and treated as mentioned in the grouping and dosing sections. After $1 \mathrm{~h}$ of dosing, $0.5 \mathrm{ml}$ of castor oil (CO) (Jordan Amman Pharmaceutical Industry $\mathrm{CO}$ ) was administered orally. Then each mouse was placed in a separate cage lined with transparent paper. The transparent paper was changed every $1 \mathrm{~h}$ for $4 \mathrm{~h}$ of observation. During the observation period, time of onset of diarrhea (time of first diarrhea following castor oil administration), number and weight of total and wet feces were measured. All, 100\% of the feces of the negative control group were assumed to be wet feces (diarrhea). The percentage of diarrhea inhibition was calculated according to the following formula [23].

$$
\begin{aligned}
& \% I D=\frac{\text { Mean number of }(\text { WFNC }- \text { WFT })}{\text { Mean number of WFNC }} \times 100 \\
& \% I T F O=\frac{\text { Mean number of }(\text { TFC }- \text { TFT })}{\text { Mean number of TFC }} \times 100
\end{aligned}
$$

Where, ID =inhibition of diarrhea, WFNC = wet feces in the negative control group, WFT=wet feces in the test group, ITFO=Inhibition of total fecal output, TFC = total feces of control, and TFT=total feces of treated.

\section{Castor oil-induced enteropooling}

The activity of crude extracts and solvent fractions in reducing intestinal secretion induced by castor oil was determined according to the method applied by Chitme 
et al. [24]. The mice were fasted for $18 \mathrm{~h}$ for food but had free access to water. Then the mice were randomly grouped and treated as described in the grouping and dosing section. One hour after oral administration, $0.5 \mathrm{ml}$ of $\mathrm{CO}$ was administered orally to each mouse. After waiting for an hour, the animals were sacrificed by cervical dislocation, followed by laparotomy with a surgical blade. The small intestine was then cut from the pylorus and cecum and ligated at both ends. Intestinal weight was measured before and after removing bowel contents and the difference was calculated. The intestinal content was removed by milking into the calibrated cylinder for volume measurement. Finally, the percentage reduction in weight and volume of the intestinal content relative to the negative control was measured using the following formula.

$$
\% R W I=\frac{M W(g)(\text { negative control }- \text { treated group })}{M W(g) \text { in the negative control }} \times 100
$$

Delhi) suspension in distilled water using oral gavage. After $30 \mathrm{~min}$ of charcoal meal administration, the animals were sacrificed by cervical dislocation, followed by the opening of the abdominal cavity and dissection of the small intestine from the junction of the pylorus and the cecum. The total length of the isolated intestine was measured with a ruler, and the distance the charcoal moves (from the end of the pylorus to the last charcoal spot) was measured and expressed by the peristaltic index (PI), thus determining the percent inhibition of motility using of the formula below.

$$
P I=\frac{\text { Distance traveled by the charcoal marker }}{\text { The total length of the small intestine }} \times 100
$$

\%Inhibition of motility $=\frac{P I(\text { negative control }- \text { test })}{\text { PI negative control }} \times 100$

$$
\% R V I C=\frac{M V I C(\mathrm{ml})(\text { negative control }- \text { treated group })}{M V I C(m l) \text { in the negative control }} \times 100
$$

\section{In vivo antidiarrheal index}

In vivo antidiarrheal index (ADI) is the measure of the antidiarrheal effectiveness of the plant. It is mathematically calculated based on the formula given below [26].

$$
\text { In vivo } A D I=\sqrt[3]{D \text { freq } \times \text { Gmeq } \times P \text { freq }}
$$

$$
D f r e q=\frac{\text { mean onset of diarrhea in (treated group }- \text { negative control group) }}{\text { mean on set of diarrhea in the negative control group }} \times 100
$$

Where, $\% R W I=\%$ reduction in weight of intestinal content, $\% R V I C=\%$ reduction in the volume of intestinal content, $M W=$ mean weight of intestine, $M V I C=$ mean volume of intestinal content

\section{Antimotility test}

The antimotility activity of the crude extract and the solvent fraction was evaluated according to the method described by Teferi et al. [25]. The mice fasted for $18 \mathrm{~h}$ for food and free access to water. The fasted animals were randomly grouped and treated as indicated in the sections on grouping and dosing. After $30 \mathrm{~min}$ of dosing, $0.5 \mathrm{ml}$ of $\mathrm{CO}$ was administered and waited a further $30 \mathrm{~min}$ to administer $0.5 \mathrm{ml}$ of marker charcoal (Acuro Organics Ltd, New
Where, Dfreq is the delay in defecation time or diarrhea onset, Gmeq is the charcoal meal travel reduction (as \% of the negative control) from the gastrointestinal motility test model, and Pfreq is the reduction in the number of wet stools (as \% of the negative control) from the castor oil-induced diarrhea model.

\section{Statistical analysis}

The results were presented as the mean \pm standard error of the mean (mean \pm SEM). Data analysis was performed by one-way ANOVA followed by Tukey's post hoc test using SPSS version 23 statistical software, with a 95\% confidence interval. A $p$-value $<0.05$ is considered statistically significant. 


\section{Results}

\section{Castor oil-induced diarrhea}

Crude plant extracts at doses of $200 \mathrm{mg} / \mathrm{kg}$ and $400 \mathrm{mg} /$ $\mathrm{kg}$ delayed the onset of diarrhea and significantly reduced the weight of wet feces $(p<0.001)$ compared to the negative control. The $100 \mathrm{mg} / \mathrm{kg}$ crude extract also significantly reduced wet feces weight $(p<0.05)$ compared to the negative control. The crude extract at $400 \mathrm{mg} /$ $\mathrm{kg}$ significantly delayed the time to onset of diarrhea $(p<0.001)$ compared to its $100 \mathrm{mg} / \mathrm{kg}$. AF at $400 \mathrm{mg} / \mathrm{kg}$ delayed the onset of diarrhea and significantly reduced whole, wet feces weight $(p<0.001)$ compared to negative controls. While at a dose of $200 \mathrm{mg} / \mathrm{kg}$, it delayed the onset of diarrhea and significantly decreased the number and weight of wet feces $(p<0.01)$ compared to the negative control. CF at $400 \mathrm{mg} / \mathrm{kg}$ delayed the onset of diarrhea and significantly reduced total and wet feces weight $(p<0.001)$ compared to negative controls. AF and $\mathrm{CF}$ at $400 \mathrm{mg} / \mathrm{kg}$ significantly delayed the onset of diarrhea compared to their $100 \mathrm{mg} / \mathrm{kg}$ and $200 \mathrm{mg} / \mathrm{kg}$ and were comparable to the effects of loperamide. NHF at $400 \mathrm{mg} / \mathrm{kg}(p<0.05)$ reduced the total feces weight compared to the negative control. The crude extract, $\mathrm{AF}$, and CF at $400 \mathrm{mg} / \mathrm{kg}$ inhibited diarrhea above $50 \%$ (Table 1).

\section{Castor oil-induced enteropooling}

The crude extract at $200 \mathrm{mg} / \mathrm{kg}$ and $400 \mathrm{mg} / \mathrm{kg}$ significantly decreased both the weight and volume of the intestinal contents $(p<0.001)$ compared to the negative control. Furthermore, $100 \mathrm{mg} / \mathrm{kg}$ of the crude extract significantly reduced the weight and volume of the intestinal contents $(p<0.01)$ compared to the negative control. The effect of $400 \mathrm{mg} / \mathrm{kg}$ of crude extract was comparable to that of loperamide. Besides, the crude extract at $400 \mathrm{mg} /$ $\mathrm{kg}$ significantly reduced the weight and volume of the intestinal content $(p<0.001)$ compared to its $100 \mathrm{mg} /$ $\mathrm{kg}$. A high percentage $(75.0 \%)$ reduction in intestinal content volume was achieved with loperamide, followed by crude extract $(70.83 \%)$ at $400 \mathrm{mg} / \mathrm{kg}$. AF at $200 \mathrm{mg} /$ $\mathrm{kg}$ and $400 \mathrm{mg} / \mathrm{kg}$ significantly reduced intestinal contents weight and volume $(p<0.001)$ compared with negative controls. Furthermore, AF at $400 \mathrm{mg} / \mathrm{kg}$ significantly reduced the weight and volume of the intestinal contents compared with its $100 \mathrm{mg} / \mathrm{kg}$ and had an effect comparable to that of loperamide. CF at $200 \mathrm{mg} / \mathrm{kg}(p<0.01)$ and $400 \mathrm{mg} / \mathrm{kg}(p<0.001)$ significantly reduced the weight and volume of intestinal content compared with the negative control. NHF at $400 \mathrm{mg} / \mathrm{kg}$ significantly reduced the weight and volume of intestinal contents $(p<0.05)$ compared with the negative control (Table 2).

Table 1 Effects of crude extract and solvent fractions of the leaf of B. abyssinica on castor oil-induced diarrhea

\begin{tabular}{|c|c|c|c|c|c|c|c|}
\hline Types of treatment & $O D$ (min) & TNF & NWF & WTF (g) & $W W F(g)$ & $\%$ ITFO & $\%$ ID \\
\hline NC & $64.50 \pm 2.17$ & $9.83 \pm 0.70$ & $7.50 \pm 0.56$ & $0.62 \pm 0.02$ & $0.50 \pm 0.02$ & -- & --- \\
\hline Loperamide (3 mg/kg) & $118.5 \pm 4.12$ & $5.83 \pm 0.70$ & $2.50 \pm 0.42$ & $0.31 \pm 0.03$ & $0.15 \pm 0.02$ & 40.69 & 66.67 \\
\hline \multicolumn{8}{|l|}{ Crude extract (mg/kg) } \\
\hline 100 & $76.00 \pm 2.31^{\text {b3e3 }}$ & $9.50 \pm 0.76^{b 1}$ & $6.33 \pm 0.49^{\mathrm{b} 3 \mathrm{e} 1}$ & $0.50 \pm 0.53^{\mathrm{a} 1 \mathrm{~b} 2}$ & $0.37 \pm 0.02^{\text {a2b } 3 \mathrm{~d} 1 \mathrm{e} 2}$ & 3.36 & 15.6 \\
\hline 200 & $90.67 \pm 4.40^{\mathrm{a} 3 \mathrm{~b} 3}$ & $7.17 \pm 0.83$ & $4.5 \pm 0.43^{\mathrm{a} 2 \mathrm{~b} 1}$ & $0.35 \pm 0.03^{\mathrm{a} 3}$ & $0.21 \pm 0.0^{\mathrm{a} 3 \mathrm{c} 1}$ & 27.06 & 40 \\
\hline 400 & $102.33 \pm 5.1^{\text {a3b1c3 }}$ & $6.67 \pm 0.71^{\mathrm{a} 1}$ & $2.83 \pm 0.31^{\mathrm{a} 3 \mathrm{c} 1}$ & $0.34 \pm 0.01^{\mathrm{a} 3}$ & $0.16 \pm 0.02^{\mathrm{a} 3 \mathrm{c} 2}$ & 32.15 & 62.67 \\
\hline \multicolumn{8}{|l|}{$\mathrm{AF}(\mathrm{mg} / \mathrm{kg})$} \\
\hline 100 & $80.83 \pm 3.20^{\text {a1b } 3 \mathrm{e} 2}$ & $9.50 \pm 0.85^{\mathrm{b} 1}$ & $6.50 \pm 0.50^{\mathrm{b} 3 \mathrm{e} 1}$ & $0.59 \pm 0.02^{\mathrm{b} 3 \mathrm{e} 3}$ & $0.43 \pm 0.03^{\mathrm{b} 3 \mathrm{e} 3}$ & 3.36 & 13.33 \\
\hline 200 & $87.00 \pm 2.13^{\mathrm{a} 2 \mathrm{~b} 3 \mathrm{e} 1}$ & $8.00 \pm 0.82$ & $4.50 \pm 0.62^{\mathrm{a} 2}$ & $0.55 \pm 0.02^{\mathrm{b} 3 \mathrm{e} 2}$ & $0.35 \pm 0.04^{\mathrm{a} 2 \mathrm{~b} 3 \mathrm{e} 2}$ & 18.62 & 40 \\
\hline 400 & $104.50 \pm 5.13^{\mathrm{a} 3 \mathrm{c} 2 \mathrm{~d} 1}$ & $6.83 \pm 0.70$ & $3.00 \pm 0.37^{\mathrm{a} 3 \mathrm{c} 1}$ & $0.34 \pm 0.03^{\mathrm{a} 3 \mathrm{c} 3 \mathrm{~d} 2}$ & $0.16 \pm 0.02^{\mathrm{a} 3 c 3 \mathrm{~d} 2}$ & 30.52 & 60 \\
\hline \multicolumn{8}{|l|}{$\mathrm{CF}(\mathrm{mg} / \mathrm{kg})$} \\
\hline 100 & $77.50 \pm 3.04^{\mathrm{b} 3 \mathrm{e} 3}$ & $9.33 \pm 0.84^{b 1}$ & $6.33 \pm 0.71^{b 2}$ & $0.55 \pm 0.04^{\mathrm{b} 3 \mathrm{e} 1}$ & $0.37 \pm 0.04^{\mathrm{b} 3 \mathrm{e} 2}$ & 5.09 & 15.6 \\
\hline 200 & $86.00 \pm 2.86^{\text {a2b3e } 1}$ & $8.67 \pm 0.88$ & $5.33 \pm 0.71^{b 1}$ & $0.45 \pm 0.05^{\mathrm{a} 1}$ & $0.26 \pm 0.02^{\mathrm{a} 3}$ & 11.80 & 28.93 \\
\hline 400 & $105.33 \pm 4.65^{\mathrm{a} 3 \mathrm{c} 3 \mathrm{~d} 1}$ & $6.83 \pm 0.75$ & $3.50 \pm 0.56^{\mathrm{a} 2}$ & $0.37 \pm 0.01^{\mathrm{a} 3 \mathrm{c} 1}$ & $0.17 \pm 0.02^{\mathrm{a} 3 \mathrm{c} 2}$ & 30.52 & 53.33 \\
\hline \multicolumn{8}{|l|}{$\mathrm{NHF}(\mathrm{mg} / \mathrm{kg})$} \\
\hline 100 & $66.67 \pm 2.14^{\mathrm{b} 3}$ & $9.33 \pm 1.15$ & $6.50 \pm 0.76^{b 1}$ & $0.58 \pm 0.03^{b 3}$ & $0.40 \pm 0.03^{\mathrm{b} 3}$ & 5.09 & 13.33 \\
\hline 200 & $67.33 \pm 2.42^{\mathrm{b} 3}$ & $8.50 \pm 1.09$ & $6.33 \pm 0.99^{\mathrm{b} 1}$ & $0.52 \pm 0.03^{\mathrm{b} 2}$ & $0.40 \pm 0.03^{\mathrm{b} 3}$ & 13.53 & 15.6 \\
\hline 400 & $73.00 \pm 2.25^{\mathrm{b} 3}$ & $7.50 \pm 1.34$ & $6.17 \pm 1.17$ & $0.48 \pm 0.04^{\mathrm{a} 1 \mathrm{~b} 2}$ & $0.37 \pm 0.05^{\mathrm{b} 2}$ & 30.52 & 17.33 \\
\hline
\end{tabular}

Results are expressed as mean $\pm \operatorname{SEM}(n=6)$; statistical analysis was performed using one-way ANOVA followed by Tukey's post hoc test. ${ }^{\mathrm{a} C o m p a r e d}$ to the negative control, ${ }^{b}$ compared to loperamide, ${ }^{c}$ compared to $100 \mathrm{mg} / \mathrm{kg}^{,}{ }^{\mathrm{d}}$ compared to $200 \mathrm{mg} / \mathrm{kg}$, ${ }^{e}$ compared to $400 \mathrm{mg} / \mathrm{kg}$. ${ }^{1} \mathrm{p}<0.05,{ }^{2} \mathrm{p}<0.01,{ }^{3} \mathrm{p}<0.001 . \mathrm{NC}$ negative control, OTD onset of diarrhea, TNF total number of feces, NWF number of wet feces, WTF weight of total feces, WWF weight of wet feces, ITFO inhibition of total fecal output, ID inhibition of diarrhea 
Table 2 Effects of crude extract and solvent fractions of the leaf of B.abyssinica on enteropooling

\begin{tabular}{|c|c|c|c|c|}
\hline Types of treatment & $\begin{array}{l}\text { Weight of intestinal } \\
\text { contents }(\mathbf{g})\end{array}$ & $\begin{array}{l}\text { The volume of the intestinal } \\
\text { contents }(\mathrm{ml})\end{array}$ & $\begin{array}{l}\text { Reduction of weight of } \\
\text { intestinal contents (\%) }\end{array}$ & $\begin{array}{l}\text { Reduction of volume of } \\
\text { the intestinal contents } \\
(\%)\end{array}$ \\
\hline NC & $0.85 \pm 0.04$ & $0.72 \pm 0.05$ & ------ & ------ \\
\hline Loperamide 3 mg/kg & $0.26 \pm 0.04$ & $0.18 \pm 0.04$ & 69.41 & 75.00 \\
\hline \multicolumn{5}{|l|}{ Crude extract (mg/kg) } \\
\hline 100 & $0.61 \pm 0.03^{\mathrm{a} 2 \mathrm{~b} 3 \mathrm{e} 3}$ & $0.50 \pm 0.05^{\mathrm{a} 2 \mathrm{~b} 3 \mathrm{e} 3}$ & 28.24 & 30.56 \\
\hline 200 & $0.48 \pm 0.04^{\mathrm{a} 3 \mathrm{~b} 2}$ & $0.37 \pm 0.04^{\mathrm{a} 3 \mathrm{~b} 1}$ & 43.53 & 48.61 \\
\hline 400 & $0.33 \pm 0.03^{\mathrm{azc} 3}$ & $0.21 \pm 0.03^{\mathrm{azc3}}$ & 61.18 & 70.83 \\
\hline \multicolumn{5}{|l|}{$\mathrm{AF}(\mathrm{mg} / \mathrm{kg})$} \\
\hline 100 & $0.64 \pm 0.02^{\mathrm{a} 2 \mathrm{~b} 3 \mathrm{e} 3}$ & $0.54 \pm 0.02^{\mathrm{a} 2 \mathrm{~b} 3 \mathrm{e} 2}$ & 24.71 & 25.00 \\
\hline 200 & $0.50 \pm 0.03^{\mathrm{a} 3 \mathrm{~b} 3}$ & $0.46 \pm 0.03^{\mathrm{a} 3 \mathrm{~b} 3}$ & 41.18 & 36.11 \\
\hline 400 & $0.35 \pm 0.03^{\mathrm{a} 3 \mathrm{c} 3}$ & $0.31 \pm 0.03^{\mathrm{a} 3 \mathrm{c} 2}$ & 58.82 & 56.94 \\
\hline \multicolumn{5}{|l|}{ CF(mg/kg) } \\
\hline 100 & $0.67 \pm 0.02^{\mathrm{a} 1 \mathrm{~b} 3}$ & $0.57 \pm 0.02^{b 3}$ & 21.18 & 20.83 \\
\hline 200 & $0.66 \pm 0.04^{\mathrm{a} 2 \mathrm{~b} 3}$ & $0.55 \pm 0.04^{\mathrm{a} 2 \mathrm{~b} 3}$ & 22.35 & 23.61 \\
\hline 400 & $0.53 \pm 0.04^{\mathrm{a} 3 \mathrm{~b} 3}$ & $0.42 \pm 0.04^{\mathrm{a} 3 \mathrm{~b} 2}$ & 37.65 & 41.67 \\
\hline \multicolumn{5}{|l|}{$\mathrm{NHF}(\mathrm{mg} / \mathrm{kg})$} \\
\hline 100 & $0.81 \pm 0.04^{\mathrm{b} 3}$ & $0.69 \pm 0.05^{b 3}$ & 4.71 & 4.17 \\
\hline 200 & $0.79 \pm 0.03^{b 3}$ & $0.68 \pm 0.03^{b 3}$ & 7.06 & 5.56 \\
\hline 400 & $0.67 \pm 0.04^{\mathrm{a} 1 \mathrm{~b} 3}$ & $0.53 \pm 0.04^{\mathrm{a} 1 \mathrm{~b} 3}$ & 21.18 & 20.83 \\
\hline
\end{tabular}

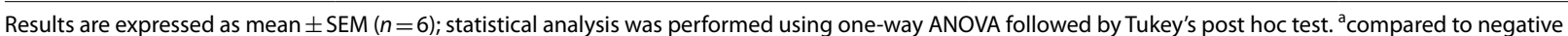
control, ${ }^{b}$ compared to loperamide, ${ }^{C}$ compared to $100 \mathrm{mg} / \mathrm{kg},{ }^{d}$ compared to $200 \mathrm{mg} / \mathrm{kg},{ }^{e}$ compared to $400 \mathrm{mg} / \mathrm{kg} .{ }^{1} \mathrm{p}<0.05,{ }^{2} \mathrm{p}<0.01,{ }^{3} \mathrm{p}<0.001$. $N C$ negative control

Table 3 Effects of crude extract and solvent fractions of the leaves of B. abyssinica on intestinal motility

\begin{tabular}{|c|c|c|c|c|}
\hline Types of treatment & $\begin{array}{l}\text { The total length of the } \\
\text { intestine }(\mathrm{cm})\end{array}$ & $\begin{array}{l}\text { Length of intestine marked with } \\
\text { charcoal }(\mathrm{cm})\end{array}$ & PI (\%) & $\begin{array}{l}\text { Inhibition of } \\
\text { motility (\%) }\end{array}$ \\
\hline NEC & $57.58 \pm 0.87$ & $33.75 \pm 1.57$ & $58.76 \pm 3.26$ & --------- \\
\hline Atropine 5 mg/kg & $58.50 \pm 0.80$ & $18.75 \pm 1.57$ & $32.03 \pm 2.62$ & 45.49 \\
\hline \multicolumn{5}{|l|}{ Crude extract (mg/kg) } \\
\hline 100 & $59.83 \pm 1.72$ & $27.25 \pm 1.67^{\mathrm{b} 1}$ & $45.83 \pm 3.48^{b 1}$ & 22.00 \\
\hline 200 & $57.5 \pm 0.61$ & $25.17 \pm 1.81^{\mathrm{a} 1}$ & $43.92 \pm 3.54^{\mathrm{a} 1}$ & 25.26 \\
\hline 400 & $57.73 \pm 0.95$ & $23.33 \pm 1.76^{\mathrm{a} 2}$ & $40.48 \pm 3.17^{\mathrm{a} 2}$ & 31.11 \\
\hline \multicolumn{5}{|l|}{$\mathrm{AF}(\mathrm{mg} / \mathrm{kg})$} \\
\hline 100 & $55.92 \pm 0.72$ & $25.67 \pm 1.08^{\mathrm{a} 2 \mathrm{~b} 1}$ & $45.93 \pm 1.97^{\mathrm{a} 1 \mathrm{~b} 2}$ & 21.83 \\
\hline 200 & $56.42 \pm 1.00$ & $23.33 \pm 1.26^{\mathrm{a} 3}$ & $41.43 \pm 2.39^{\mathrm{a} 2}$ & 29.49 \\
\hline 400 & $57.00 \pm 0.76$ & $22.42 \pm 1.34^{\mathrm{a} 3}$ & $39.47 \pm 2.82^{\mathrm{a} 3}$ & 32.83 \\
\hline \multicolumn{5}{|l|}{ CF $(\mathrm{mg} / \mathrm{kg})$} \\
\hline 100 & $57.75 \pm 1.24$ & $31.33 \pm 1.42^{\mathrm{b} 3 \mathrm{e} 2}$ & $54.24 \pm 2.06^{\mathrm{b} 3 \mathrm{e} 2}$ & 7.69 \\
\hline 200 & $57.92 \pm 1.36$ & $28.67 \pm 2.00^{\mathrm{b} 2}$ & $49.30 \pm 2.67^{b 3}$ & 16.10 \\
\hline 400 & $57.67 \pm 2.46$ & $21.33 \pm 1.60^{\mathrm{a} 3 \mathrm{c} 2}$ & $36.89 \pm 1.89^{\mathrm{a} 3 \mathrm{c} 2}$ & 37.22 \\
\hline \multicolumn{5}{|l|}{$\mathrm{NHF}(\mathrm{mg} / \mathrm{kg})$} \\
\hline 100 & $57.83 \pm 1.07$ & $31.83 \pm 1.49^{\mathrm{b} 3 \mathrm{e} 2}$ & $55.16 \pm 2.86^{\mathrm{b} 3 \mathrm{e} 2}$ & 6.13 \\
\hline 200 & $57.17 \pm 1.12$ & $30.08 \pm 1.65^{\mathrm{b} 3 \mathrm{e} 1}$ & $52.88 \pm 3.32^{\mathrm{b} 2 \mathrm{e} 1}$ & 10.01 \\
\hline 400 & $58.08 \pm 0.98$ & $21.75 \pm 1.53^{\mathrm{a} 3 \mathrm{c} 2 \mathrm{~d} 1}$ & $37.67 \pm 3.30^{\mathrm{a} 2 \mathrm{c} 2 \mathrm{~d} 1}$ & 35.89 \\
\hline
\end{tabular}




\section{Antimotility test}

The crude extract at $400 \mathrm{mg} / \mathrm{kg}$ inhibited the movement of a charcoal meal within the small intestine and decreased the PI significantly $(p<0.01)$ compared to the negative control. Besides, the crude extract at $200 \mathrm{mg} /$ $\mathrm{kg}$ inhibited the movement of the charcoal meal within the small intestine and decreased the PI significantly $(p<0.05)$ compared to the negative control. Both $200 \mathrm{mg} /$ $\mathrm{kg}$ and $400 \mathrm{mg} / \mathrm{kg}$ of the crude extract inhibited the movement of the charcoal meal and decreased the PI comparable to the effect of atropine. The percent inhibition of motility was obtained with the crude extract and its solvent fractions ( Table 3 ).

The AF at $200 \mathrm{mg} / \mathrm{kg}$ and $400 \mathrm{mg} / \mathrm{kg}$ inhibited the movement of a charcoal meal within the small intestine significantly $(p<0.001)$ compared to the negative control and had a comparable effect to the effect of atropine. Besides, the AF at $100 \mathrm{mg} / \mathrm{kg}$ inhibited the movement of charcoal meal within the small intestine significantly $(p<0.01)$ compared to the negative control. The CF at $400 \mathrm{mg} / \mathrm{kg}$ inhibited the movement of a charcoal meal within the small intestine and decreased the PI significantly $(p<0.001)$ compared to the negative control and had a comparable effect to the effect of atropine. In addition, the $C F$ at $400 \mathrm{mg} / \mathrm{kg}$ inhibited the movement of the charcoal meal and decreased the PI significantly $(p<0.01)$ compared to its $100 \mathrm{mg} / \mathrm{kg}$. The NHF at

Table 4 In Vivo ADI of crude extract and solvent fractions of the leaves of $B$. abyssinica

\begin{tabular}{|c|c|c|c|c|}
\hline Groups & Dfreq (\%) & Gmeq ( \%) & Pfreq (\%) & ADI (\%) \\
\hline \multicolumn{5}{|c|}{ Crude extract (mg/kg) } \\
\hline 100 & 18.75 & 22.00 & 15.60 & 18.06 \\
\hline 200 & 41.67 & 25.26 & 40.00 & 33.58 \\
\hline 400 & 59.89 & 31.11 & 62.27 & 46.91 \\
\hline \multicolumn{5}{|c|}{ AF (mg/kg) } \\
\hline 100 & 26.30 & 21.83 & 13.33 & 19.13 \\
\hline 200 & 35.94 & 29.49 & 40.00 & 33.65 \\
\hline 400 & 63.28 & 32.83 & 60.00 & 48.04 \\
\hline \multicolumn{5}{|c|}{ CF (mg/kg) } \\
\hline 100 & 20.16 & 7.69 & 15.6 & 13.08 \\
\hline 200 & 33.33 & 16.10 & 28.93 & 24.16 \\
\hline 400 & 63.30 & 37.22 & 53.33 & 48.16 \\
\hline \multicolumn{5}{|c|}{ NHF(mg/kg) } \\
\hline 100 & 3.36 & 6.13 & 13.33 & 6.38 \\
\hline 200 & 4.39 & 10.01 & 15.6 & 8.63 \\
\hline 400 & 13.18 & 35.89 & 17.33 & 19.57 \\
\hline \multicolumn{5}{|c|}{ Positive control } \\
\hline & 83.72 & 45.49 & 66.67 & 60.75 \\
\hline
\end{tabular}

Dfreq Delay in the onset of diarrhea, Gmeq reduction in intestinal transit, Pfreq reduction in the number of wet stools
$400 \mathrm{mg} / \mathrm{kg}$ inhibited the movement of the charcoal meal and decreased the PI significantly compared to the negative control and its 100 and $200 \mathrm{mg} / \mathrm{kg}$.

\section{In vivo antidiarrheal index (ADI)}

The ADI of both the crude extract and solvent fractions increased with increasing the dose (Table 4). For instance, ADI of the crude extract increased from $18.06 \%$ at $100 \mathrm{mg} / \mathrm{kg}$ to $46.91 \%$ at $400 \mathrm{mg} / \mathrm{kg}$.

\section{Discussion}

Hydromethanol (80\% methanol) can extract non-polar to polar phytochemicals [27]. For this reason, $80 \%$ methanol was used as the initial extracting solvent. The in vivo antidiarrheal activity of crude extracts and solvent fractions was evaluated in three models of diarrhea using CO. Ricinoleic acid, the pharmacologically active component of $\mathrm{CO}$ binds to and activates the prostanoid EP3 receptor. Ricinoleic acid stimulates the synthesis of endogenous prostaglandins from arachidonic acid in the intestine. Prostaglandins improve gastrointestinal motility, produce a laxative effect, and alter the movement of water and electrolytes in and out of the intestinal lumen $[28,29]$. Therefore, the use of CO to induce diarrhea is analogous to the pathophysiology of diarrhea and reasonable to use in this study.

The anti-diarrheal activities of medicinal plants are related to phytochemical constituents including flavonoids, tannins, saponins, sugars, sterols, and/or terpenes $[30,31]$. The leaves of $B$. abyssinica contain most of the listed phytochemicals that contribute to its anti-diarrheal activities observed in this study. The mode of action of the antidiarrheal activities of extracts of traditional MPs involves antisecretory activity, favoring intestinal absorption, antispasmodic or antimotility, anti-microbial, and antispasmodic action [32, 33].

After administration of $\mathrm{CO}$ at a dose of $0.1-0.3 \mathrm{ml}$, diarrhea occurs within 1 to $2 \mathrm{~h}$ [34]. In this study, $\mathrm{CO}$ was administered at a dose of $0.5 \mathrm{ml}$ and negative controls showed diarrhea for an average of $64.5 \mathrm{~min}$. Semipolar secondary metabolites are required to delay the onset of diarrhea [35]. This may justify the observed effect of the crude extract and AF at $200 \mathrm{mg} / \mathrm{kg}$ and $400 \mathrm{mg} / \mathrm{kg}$ and CF at $400 \mathrm{mg} / \mathrm{kg}$ to delay or alleviate diarrhea. Provided n-hexane is non-polar, the lack of activity of NHF at all three doses in delaying the onset of diarrhea may be due to the absence of semipolar secondary metabolites.

Despite the lack of a specific definition of diarrhea, fece weight and consistency are often taken into account [36]. Regarding this, the number of loose or wet feces was recorded in this study. The crude extract, $\mathrm{AF}$, and $\mathrm{CF}$ were reduced in the number of wet feces in 
a dose-dependent manner. A high percentage reduction in the number of wet feces was achieved at $400 \mathrm{mg} / \mathrm{kg}$ of crude extract, $\mathrm{AF}$, and $\mathrm{CF}$. The increase in the percentage reduction with increasing doses suggests that high doses are needed to effectively inhibit diarrhea [37].

The antisecretory activity of MPs relies on the presence of phytochemicals including tannins [38] and flavonoids [39]. From previous phytochemical screening studies, tannins and flavonoids of methanol and aqueous extracts and flavonoids (but not tannins) of chloroform extracts were identified as major phytochemical components of the leaf of B. abyssinian [3]. Thus the observed activity, in a CO-induced enteroppoling antidiarrheal model, at all three doses of the crude extract and AF and could be due to the presence of tannins and flavonoids in a dose-dependent manner. Similarly, observed antisecretory activity of $200 \mathrm{mg} /$ $\mathrm{kg}$ and $400 \mathrm{mg} / \mathrm{kg}$ of CF is related to the presence of flavonoids while lack of activity at $100 \mathrm{mg} / \mathrm{kg}$ could be due to the absence of tannins and flavonoids. Only $400 \mathrm{mg} / \mathrm{kg}$ of NHF showed antisecretory activity may be due to tannins and/or flavonoids being only available at high doses of NHF. A shred of evidence suggests that plant extracts may contain denatured proteins that produce tenant proteins that act as a protective shade for the intestinal lining and reduce secretion [40]. Thus, a decrease in the weight and volume of the intestinal contents in the crude extract and the fractions of the solvent, probably due to the presence of both antisecretory phytochemicals and denatured proteins.

The anti-motility activity of medicinal plants extracts is related to phytochemicals such as tannins, flavonoids, and alkaloids [41]. Based on this the observed antimotility activity at $200 \mathrm{mg} / \mathrm{kg}$ and $400 \mathrm{mg} / \mathrm{kg}$ of crude extract and all three doses of AF related to the presence of mentioned phytochemicals. As such, the lack of antimotility activity at $100 \mathrm{mg} / \mathrm{kg}$ of the crude extract may be related to the absence or low levels of tannins, alkaloids, and flavonoids. In addition, aqueous extract of leaf of B. abyssinica was reported to have antispasmodic activity (16) which could contribute to the observed antimotility activity of AF at all three doses. The antimotility activity showed at $400 \mathrm{mg} / \mathrm{kg}$ and lack of activity at $100 \mathrm{mg} / \mathrm{kg}$ and $200 \mathrm{mg} / \mathrm{kg}$ of CF and NHF could be related to the presence and absence or low amount of antimotility phytochemicals, respectively.

ADI is a measure of relative effectiveness for diarrhea inhibition [27]. In this study, ADI was increased in a dose-dependent manner. Although the highest ADI was achieved at $400 \mathrm{mg} / \mathrm{kg}$ CF it had the lowest ADI at $100 \mathrm{mg} / \mathrm{kg}$ and $200 \mathrm{mg} / \mathrm{kg}$ compared with equal doses of the crude extract and AF. This suggests that
CF has less antidiarrheal activity at $100 \mathrm{mg} / \mathrm{kg}$ and $200 \mathrm{mg} / \mathrm{kg}$.

\section{Conclusion}

The results of this study showed that the crude extract and $\mathrm{AF}$ and CF of B. abyssinica fresen leaves had significant antidiarrheal activity. This supports the use of the plant in the treatment of diarrhea in traditional medicine, while further studies are required to isolate the specific phytochemicals responsible for the antidiarrheal activity and determine their mechanism of action at the molecular level.

\section{Abbreviations \\ AF: Aqueous fraction; ADI: Antidiarrheal index; CF: Chloroform fraction; CO: Castor oil; MPs: Medicinal plants; NHF: N-hexane fraction; PI: Peristalsis index.}

\section{Acknowledgements}

The authors would like to thank the University of Gondar for facilitating this work.

\section{Authors' contributions}

All authors participated in the design of the study and the preparation of the manuscript for submission. MA conducted the research, analyzed statistics, and prepared the manuscript. All authors have read and approved the submitted version of the manuscript and are responsible for all aspects of the work.

\section{Funding}

No funding

\section{Availability of data and materials}

All the necessary data supporting the result and conclusion have been incorporated into the manuscript.

\section{Declarations}

\section{Ethics approval and consent to participate}

The study protocol was approved by the experimental research ethics committee of the department of pharmacology, the University of Gondar under reference number 50p4/354/12. Animals were handled and used per international guidelines for the care and use of laboratory animals. The plant material was collected after consent was obtained from a person at the collection area, based on WHO guidelines on good agricultural and collection practices (GACP) for the medicinal plant. The study was conducted in agreement with the Arrive guidelines.

\section{Consent for publication}

Not applicable

\section{Competing interests}

Authors declare no conflicting of interest.

\section{Author details}

${ }^{1}$ Department of Pharmacology, Institute of Health, Jimma University, Jimma, Ethiopia. ${ }^{2}$ Department of Social and Administrative Pharmacy, Institute of Health, Jimma University, Jimma, Ethiopia. ${ }^{3}$ Department of Pharmacology, School of Pharmacy, College of Medicine and Health Science, University of Gondar, Gondar, Ethiopia.

Received: 22 September 2021 Accepted: 23 December 2021

Published online: 06 January 2022 


\section{References}

1. Sinan Kl, Chiavaroli A, Orlando G, Bene K, Zengin G, Cziáky Z, et al. Biopotential of bersama abyssinica fresen stem bark extracts: UHPLC profiles, antioxidant, enzyme inhibitory, and antiproliferative propensities. Antioxidants. 2020;9(2):163.

2. Geyid A, Abebe D, Debella A, Makonnen Z, Aberra F, Teka F, et al. Screening of some medicinal plants of Ethiopia for their anti-microbial properties and chemical profiles. J Ethnopharmacol. 2005;97(3):421-7.

3. Anza M, Worku F, Libsu S, Mamo F, Endale M. Phytochemical screening and antibacterial activity of leaves extract of Bersama abyssinica. J Adv Bot Zool. 2015:3(2):1-5.

4. Sinan Kl, Bene K, Zengin G, Diuzheva A, Jekő J, Cziáky Z, et al. A comparative study of the HPLC-MS profiles and biological efficiency of different solvent leaf extracts of two African plants: Bersama abyssinica and Scoparia dulcis. International Journal of Environmental Health Research. 2019:1-13.

5. Schmelzer G, Gurib-Fakim A. Plant resources of tropical Africa 11 (2): medicinal plants 2. Plant resources of tropical Africa 11 (2): medicinal plants 2. 2013.

6. Zekeya N, Chacha M, Shahada F, Kidukuli A. Analysis of phytochemical composition of Bersama abyssinica by gas chromatography-mass spec trometry. 2014

7. Fenetahun Y, Eshetu G. A review on ethnobotanical studies of medicinal plants use by agro-pastoral communities in Ethiopia. J Med Plants. 2017:5(1):33-44

8. Getaneh S, Girma Z. An ethnobotanical study of medicinal plants in Debre Libanos Wereda, Central Ethiopia. Afr J Plant Sci. 2014;8(7):366-79.

9. Birhanu Z. Traditional use of medicinal plants by the ethnic groups of Gondar Zuria District North-Western Ethiopia. Journal of Natural Remedies. 2013:13(1):46-53.

10. Regassa R. Assessment of indigenous knowledge of medicinal plant practice and mode of service delivery in Hawassa city, southern Ethiopia. Journal of Medicinal Plants Research. 2013;7(9):517-35.

11. Lulekal E, Rondevaldova J, Bernaskova E, Cepkova J, Asfaw Z, Kelbessa E, et al. Antimicrobial activity of traditional medicinal plants from Ankober district, north Shewa Zone, Amhara region. Ethiopia Pharmaceutical biology. 2014;52(5):614-20

12. Alehegn AA, Yesuf JS, Birru EM. Antimalarial Activity of Crude Extract and Solvent Fractions of the Leaves of Bersama abyssinica Fresen.(Melianthaceae) against Plasmodium berghei Infection in Swiss Albino Mice. Evid Based Complement Alternat Med. 2020;2020:9467359.

13. Ameya G, Manilal A, Idhayadhulla A. Phytochemical analysis and antimicrobial activity of Bersama abyssinica Fresen against multidrug-resistant bacterial uropathogens: picolinyl hydrazide is a major compound. J Herbs Spices Med Plants. 2019;25(4):389-400.

14. Asian J. In-vitro antihelmentic evaluaion of leaf extract of Bersama Abyssinica (Mellanthaceae) on Haemonchus Contortus. Asian J Med Pharm Res. 2018;8(2):05-14.

15. Asres K, Bucar F, Kartnig T, Witvrouw M, Pannecouque C, De Clerca E. Antiviral activity against human immunodeficiency virus type 1 (HIV-1) and type 2 (HIV-2) of ethnobotanically selected Ethiopian medicinal plants. Phytotherapy Research: An International Journal Devoted to Pharmacological and Toxicological Evaluation of Natural Product Derivatives. 2001:15(1):62-9.

16. Bene K, Kra AKM, Konan KF, Zirihi GN. Bersama abyssinica Fresen.(Melianthaceae): Antifungal activity on aflatoxin B1-producing mold. Journal of Pharmaceutical Research International. 2017;15(1):1-6.

17. Makonnen E, Hagos E. Antispasmodic effect of Bersama abyssinica aqueous extract on guinea-pig ileum. Phytother Res. 1993;7(2):211-2.

18. Council NR. Guide for the care and use of laboratory animals: National Academies Press; 2010.

19. Ezeja IM, Ezeigbo II, Madubuike KG, Udeh NE, Ukweni IA, Akomas SC, et al. Antidiarrheal activity of Pterocarpus erinaceus methanol leaf extract in experimentally-induced diarrhea. Asian Pac J Trop Med. 2012;5(2):147-50

20. Kifle ZD, Enyew EF. Evaluation of In Vivo Antidiabetic, In Vitro a-Amylase Inhibitory, and In Vitro Antioxidant Activity of Leaves Crude Extract and Solvent Fractions of Bersama abyssinica Fresen (Melianthaceae). J Evid Based Integr Med. 2020;25:2515690X20935827.

21. Abdela J. Evaluation of in vivo antidiarrheal activities of hydroalcoholic leaf extract of Dodonaea viscosa L.(Sapindaceae) in Swiss Albino Mice. J Evid Based Integr Med. 2019;24:2515690X19891952.
22. Awouters F, Niemegeers C, Lenaerts F, Janssen P. Delay of castor oil diarrhoea in rats: a new way to evaluate inhibitors of prostaglandin biosynthesis. J Pharm Pharmacol. 1978;30(1):41-5.

23. Ezekwesili C, Obiora K, Ugwu O. Evaluation of Anti-Diarrhoeal Property of Crude Aqueous Extract of Ocimum gratissimum L.(Labiatae) In Rats. 2004

24. Chitme HR, Chandra R, Kaushik S. Studies on anti-diarrhoeal activity of Calotropis gigantea R. Br. in experimental animals. J Pharm Pharm Sci. 2004;7(1):70-5

25. Teferi MY, Abdulwuhab M, Yesuf JS. Evaluation of in vivo antidiarrheal activity of $80 \%$ methanolic leaf extract of Osyris quadripartita Decne (Santalaceae) in Swiss Albino Mice. J Evid Based Integr Med. 2019;24:2515690X19833340.

26. Than A, Kulkarni HJ, Hmone W, Tha S. Anti-diarrhoeal efficacy of some Burmese indigenous drug formulations in experimental diarrhoeal test models. International Journal of Crude Drug Research. 1989;27(4):195-200.

27. Zayede D, Mulaw T, Kahaliw W. Antidiarrheal activity of hydromethanolic root extract and solvent fractions of Clutia abyssinica Jaub. \& Spach.(Euphorbiaceae) in Mice. Evid Based Complement Alternat Med. 2020:2020:5416749.

28. Tunaru S, Althoff TF, Nüsing RM, Diener M, Offermanns S. Castor oil induces laxation and uterus contraction via ricinoleic acid activating prostaglandin EP3 receptors. Proc Natl Acad Sci. 2012;109(23):9179-84.

29. Adeniyi OS, Omale J, Omeje SC, Edino VO. Antidiarrheal activity of hexane extract of Citrus limon peel in an experimental animal model. Journal of integrative medicine. 2017;15(2):158-64.

30. Meite S, N'guessan J, Bahi C, Yapi H, Djaman A, Guina FG. Antidiarrheal activity of the ethyl acetate extract of Morinda morindoides in rats. Tropical Journal of Pharmaceutical Research. 2009:8(3):201-7.

31. Emudainohwo J, Erhirhie E, Moke E. Anti-diarrheal activity of the aqueous leaf extract of Ageratum conyzoides in wistar rats. J Appl Sci Environ Manag. 2015;19(2):169-75.

32. Okoye T, Akah P, Okoli C, Ezike A, Mbaoji F. Antimicrobial and antispasmodic activity of leaf extract and fractions of Stachytarpheta cayennensis. Asian Pac J Trop Med. 2010;3(3):189-92.

33. Derebe D, Abdulwuhab M, Wubetu M, Mohammed F. Investigation of the antidiarrheal and antimicrobial activities of $80 \%$ methanolic leaf extract of discopodium penninervum (hochst.). Evid Based Complement Alternat Med. 2018;2018:1360486.

34. Tadesse WT, Hailu AE, Gurmu AE, Mechesso AF. Experimental assessment of antidiarrheal and antisecretory activity of $80 \%$ methanolic leaf extract of Zehneria scabra in mice. BMC Complement Altern Med. 2014;14(1):460

35. Mengistu G, Engidawork E, Nedi T. Evaluation of the antidiarrhoeal activity of $80 \%$ methanol extract and solvent fractions of the leaves of Lantana camara linn (Verbenaceae) in mice: Addis Ababa University; 2015.

36. Sisay $M$, Engidawork $E$, Shibeshi W. Evaluation of the antidiarrheal activity of the leaf extracts of Myrtus communis Linn (Myrtaceae) in mice model. BMC Complement Altern Med. 2017;17(1):103.

37. Mekonnen B, Asrie AB, Wubneh ZB. Antidiarrheal activity of $80 \%$ methanolic leaf extract of Justicia schimperiana. Evid Based Complement Alternat Med. 2018;2018:3037120

38. Yadav AK, Tangpu V. Antidiarrheal activity of Lithocarpus dealbata. and Urena lobata. Extracts: therapeutic implications. Pharmaceutical Biology. 2007:45(3):223-9.

39. Li Y, Li J, Liu X, Zhang J, Mei X, Zheng R, et al. Antidiarrheal activity of methanol extract of Sophora tonkinensis in mice and spasmolytic effect on smooth muscle contraction of isolated jejunum in rabbits. Pharm Biol. 2019;57(1):477-84.

40. Sini KR, Sinha BN, Rajasekaran A. Antidiarrheal activity of Capparis zeylanica leaf extracts. J Adv Pharm Tech Res. 2011;2(1):39.

41. Birru EM, Asrie AB, Adinew GM, Tsegaw A. Antidiarrheal activity of crude methanolic root extract of Idigofera spicata Forssk.(Fabaceae). BMC Complement Altern Med. 2016:16(1):272.

\section{Publisher's Note}

Springer Nature remains neutral with regard to jurisdictional claims in published maps and institutional affiliations. 